\title{
오 Field Marshal Erwin Rommel: the head injury that may have prolonged the Second World War
}

\author{
Heather A. Fuhrman, BS, ${ }^{1}$ Jeffrey P. Mullin, MD, MBA, ${ }^{2}$ and Chris A. Sloffer, MD, MBA ${ }^{3,4}$ \\ ${ }^{1}$ School of Medicine, Case Western Reserve University; ${ }^{2}$ Department of Neurosurgery, Cleveland Clinic, Cleveland, Ohio; \\ ${ }^{3}$ Bronson Neuroscience Center; and ${ }^{4}$ Western Michigan University, Homer Stryker School of Medicine, Kalamazoo, Michigan
}

\begin{abstract}
War-related head injury, indeed neurological injury in general, has been a part of the history of humankind for as long as there has been warfare. Such injuries can result in the removal of the individual from combat, thus eliminating any subsequent contribution that he or she might have made to the battle. However, at times, the injuries can have more wide-reaching effects. In the case of commanders or leaders, the impact of their injuries may include the loss of their influence, planning, and leadership, and thus have a disproportionate effect on the battle, or indeed the war. Field Marshal Erwin Rommel was a talented military strategist and leader who was respected by friends and foes alike. He held an honored reputation by the German people and the military leadership. His head injury on July 17, 1944, resulted in his being removed from the field of battle in northern France, but also meant that he was not able to lend his stature to the assassination attempt of Adolph Hitler on July 20. It is possible that, had he been able to lend his stature to the events, Hitler's hold on the nation's government might have been loosened, and the war might have been brought to an end a year earlier. The authors review Rommel's career, his injury, the subsequent medical treatment, and his subsequent death.
\end{abstract}

http://thejns.org/doi/abs/10.3171/2016.4.FOCUS15486

KEY WORDS head injury; World War II; Erwin Rommel

$\mathrm{G}$ ERMAN Field Marshal Erwin Rommel developed a reputation as one of Germany's most popular and heroic soldiers of World War II. He devised war strategies, led troops to victories, and showed respect and mercy to his captives. The near-fatal strafing of his command car on July 17, 1944, provided just the right camouflage for the Desert Fox's death; a Nazi-regime forced suicide. Rommel's death "deprived [the German people] of the only man strong enough to bear the terrible weight of war and civil war simultaneously, the only man who was straightforward enough to counter the frightful folly of the leaders of Germany." ${ }^{10}$ Rommel was accused of being involved in a conspiracy to overthrow Hitler and subsequently had to be punished. Did Rommel's head injury and skull fracture from the car accident prevent a successful German Army plot to overthrow Hitler? Could the battles and crimes against humanity of World War II have ended 10 months earlier had the Allied pilot known about the German generals' revolt and let the car pass unharmed? Was "the one who embodied the only hope that Germany had of salvation" denied the chance to act? ${ }^{2}$ The background to this perhaps history-altering episode, as well as a description of the accident, medical care administered, and ensuing events are provided here.

\section{The Young Years}

Erwin Johannes Eugen Rommel was born on November 15, 1891, to Erwin Rommel, Senior, and Helene von Luz at Heidenheim, in the Kingdom of Württemberg, then part of the German Empire. At a young age he was not drawn to academics, yet in his teenage years he excelled in mathematics and considered becoming an engineer. However, perhaps influenced by his father, who once served as a Second Lieutenant in the Army, he joined the 124th Infantry Regiment as an officer cadet..$^{2,11}$ In March 1911, he began training at the War Academy in Danzig in East Prussia, and a year later he was commissioned a lieutenant. ${ }^{11}$ While in Danzig, he met Lucia Maria Mollin, and the two married in November $1916 .^{2}$ Twelve years later they had their only child, a son named Manfred. ${ }^{11}$

\section{His Early Military Endeavors}

Rommel was initially recognized for his military performance in France, Italy, and Romania in the First World War. ${ }^{11}$ In particular, he received the Pour le Mérite, the highest German decoration, for his leadership at Monte Matajur against the Italian army. ${ }^{2}$ Despite an Allied-imposed reduction in German armed forces after the First 
World War, Rommel was able to maintain a position as Captain of a Stuttgart infantry for 9 years. ${ }^{11}$ From 1929 to 1933 he served as an instructor at the Army Infantry School in Dresden. ${ }^{2}$ His lectures on infantry tactics were compiled in his first book, Infanterie Greift An (Infantry Attacks), which he also illustrated. ${ }^{2}$ Returning to transient active duty in 1933, Rommel earned the title of Major and led the Mountain Corps at Goslar. ${ }^{2}$ In 1935 Rommel first met Hitler when the Führer, Himmler, and Goebbels, the Reich Minister of Propaganda at the time, visited Rommel's troops at Goslar. ${ }^{11}$ In October of that year he was promoted to Lieutenant Colonel. ${ }^{11}$ At this point, Rommel resumed his role as instructor, but at the War Academy in Potsdam. On November 10, 1938, he became Commandant of the War Academy at Wiener Neustadt. ${ }^{11} \mathrm{~A}$ year later Rommel was promoted to Major General, bypassing Brigadier General, and was in charge of Hitler's personal safety both in Czechoslovakia and Poland.2,11 Rommel used this opportunity and access to Hitler to request command of an armored division to participate in the approaching invasion of France. Hitler agreed, and on February 15, 1940, Rommel took over the 7th Panzer Division. ${ }^{11}$ From May 10 to June 19 of that year, Rommel's troops captured many French towns and Allied soldiers and equipment. ${ }^{11}$ His endeavors earned the unit the nickname "Ghost Division" for its swift moves and successes, while also building Rommel's famed reputation as a commander who fought from the front line. ${ }^{11}$

Rommel's tactical genius, ability to make use of limited resources, and humanitarianism earned him much respect and glory from friends and foes. Rommel heavily stressed to his troops a code of chivalry, conduct, and humanity in peace and war; Hitler considered this attitude a sign of weakness. ${ }^{10}$ Rommel's troops were never found guilty of war crimes, and he always treated captured Allied soldiers humanely. ${ }^{7}$ Rommel repudiated orders to kill Jewish soldiers, civilians, and commandos. ${ }^{4}$ As a leader he was selfaware and socially aware. He never smoked, drank only rarely, and was frugal. ${ }^{10}$ Rommel rejected invitations to special meals when he traveled to the front. ${ }^{2}$ Rather, he ate in the field kitchen to show the men that although he was a field marshal, he had no desire to live any better than they did. ${ }^{6}$ Rommel understood soldier psychology; he talked to his men about their families and gave them cigarettes and cookies. ${ }^{6}$ His aide, Captain Hermann Aldinger claimed, in an interview with Charles Marshall, "No matter how low the men's spirits when we arrived, they were high when he left." ${ }^{\prime}$ Moreover, Rommel was worshipped by his troops for his willingness to give junior officers chances to prove their worth. ${ }^{6}$ Rommel frequently commented, "Germany will need men after the war as well," and this notion extended to his prisoners. ${ }^{4}$ Rommel's moral fiber and comradery with his troops was invaluable to his rise to fame.

\section{The African Campaign}

In January 1941, Rommel was promoted to Lieutenant General and began his 2-year command of the Afrika Korps in the North African desert. ${ }^{11}$ Notably, he captured the British garrison at Tobruk, Libya, on June 21, 1942, and faced American forces for the first time in February 1943 at the Battle of Kasserine Pass. ${ }^{11}$ As a reward for his successful campaign, Hitler named Rommel Germany's youngest Field Marshal (Fig. 1) at age 50 years. ${ }^{11}$ Unfortunately for Rommel and the Axis powers in Africa, these victories were the high point in the long back-and-forth campaign across Northern Africa. By 1943, Bernard Montgomery had been given command of the Allied Eighth Army, and they were making great strides in containing the Axis advances and were beginning to force their withdrawal. To maintain a chance of victory in Africa, Rommel recommended a shortening of the front from 400 miles to 100 miles, and that the troops might be better used by removing them to Italy to defend against an invasion of southern Europe. He personally appealed to Hitler and the high command, but his recommendations were rebuffed? Rommel continued in command in Africa for a few more weeks, but departed for Germany before the battle of the Mareth Line.

There are various explanations as to why Rommel did not remain in command of his troops to the end. Brigadier

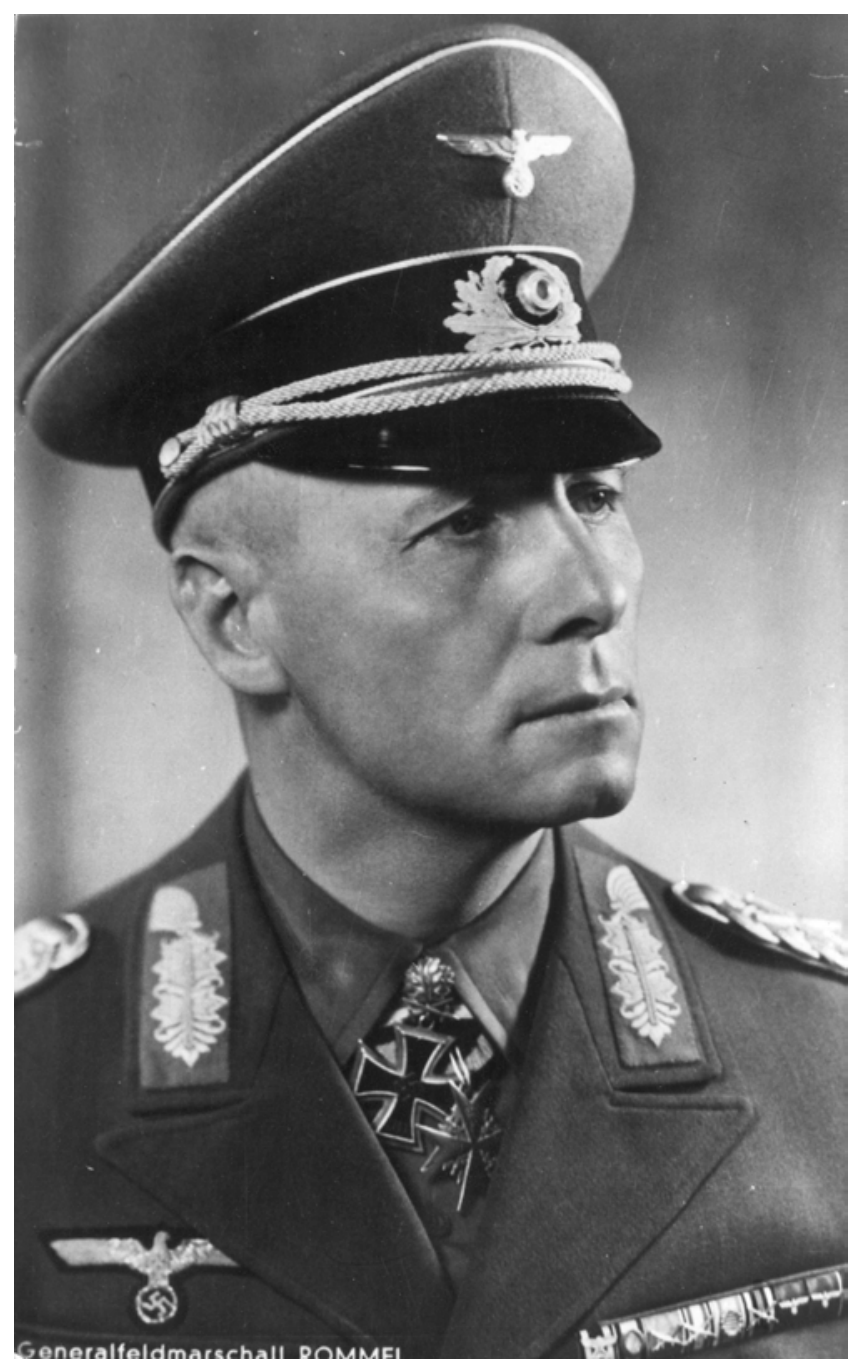

FIG. 1. Official military portrait of Field Marshal Erwin Rommel. Note the presence of his Pour le Mérite and Knight's Cross. This photograph was taken about 1943. Bundesarchiv, Bild 146-1973-012-43. CC-BY-SA 3.0; https://creativecommons.org/licenses/by-sa/3.0/. 
Desmond Young, who fought with the British in the African campaign, and wrote one of the first biographies of Rommel, describes that Rommel had flown to Germany again to ask Hitler to allow him to save the remaining troops in Africa. His request was refused, as was his request to return to return to Africa. ${ }^{13}$ The Axis powers surrendered at Tunis on May 13, 1943.

\section{Return to France}

Rommel spent the summer of 1943 first in Italy, then as a "military advisor" at Hitler's headquarters. ${ }^{13}$ On November 21, 1943, Rommel became inspector of Coastal Defenses of the Atlantic Wall. ${ }^{2,11} \mathrm{He}$ worked steadfastly at the La Roche Guyon Headquarters to reinforce defenses in preparation for an Allied invasion of France. ${ }^{11}$ Rommel disagreed with his superior, Field Marshal Gerd von Rundstedt, about where the Allies would invade. ${ }^{11}$ Rommel believed that the Army should be shifted to the beaches of Normandy, where they could contain the Allied invaders on the beach. ${ }^{2}$ However, von Rundstedt believed that the Allies would land at Pas de Calais and favored a strategy of allowing the enemies to advance to where the German Panzer force could be brought in to defeat them. ${ }^{11}$ Rommel's expectation proved to be correct when the Allies invaded Normandy on June 6, 1944. Midway through the month, the Allies had gained substantial ground into the heart of France. Rommel and von Rundstedt requested all reserves to be sent to France and a retreat for regrouping, but Hitler dismissed the request. ${ }^{11}$ On June 29, the 3 men met and both Field Marshals told Hitler the Western Front was lost. As a result, von Rundstedt was fired and replaced by Field Marshal Hans Günther von Klüge. ${ }^{11}$ On July 15, Rommel gave his final warning to Hitler that military victory was impossible in France. ${ }^{2}$

\section{Disillusionment}

Throughout the turbulent 6 months that Rommel spent in France, his mindset began to change. He learned of the Schutzstaffel (SS) crimes against humanity, particularly the Jews and Russians. ${ }^{11}$ He witnessed the internal destruction of German cities and villages, their economies, and the German youth. ${ }^{11}$ Rommel repeatedly protested against the administrative corruption that was destroying the state. He was duty-bound to partake in Goebbels's fake Atlantic Wall propaganda professing German superiority over the enemy..$^{10}$ However, when he discovered that they never mentioned Allied air dominance, Rommel immediately requested that Hitler stop these films and press releases. ${ }^{10} \mathrm{He}$ spoke of Hitler, his monstrous crimes, and his stubborn military proceedings in the following manner: "that accumulation of senseless greed in its most brutal form; desire for renown; the conqueror's dream of power; lust for killing and destruction; vainglory and paralyzing fear; thirst for vengeance; and boundless despair." 10 Rommel's early allegiance to Hitler faded as the war progressed, and his passion to stop the mounting failures only grew. He knew that if the truth were known, the German people would doubt their leaders and chaos would arise. Honesty and transparency were more important to Rommel than public perception.
Rommel's desire to save Germany from devastation was powerful. He wrote strongly worded letters to Hitler and met him in person to express his dissent. Rommel's Chief of Staff, General Hans Speidel, later observed, "Some other senior officers resigned themselves to inactivity when they saw these terrible manifestations. Rather, this awareness developed in [Rommel] a resiliency of mind and heart which prepared him for independent action."'10 Early in 1944, Karl Strölin, an old friend and fellow World War I soldier, informed Rommel about a conspiracy to capture Hitler, overthrow the Nazi Party, and offer peace to the Allies. ${ }^{2}$ Strölin said to Rommel, "You are the only one who can prevent civil war in Germany. You must lend your name to the movement."' "I did not tell him that it was proposed to make him President of the Reich: the idea was not, in fact, suggested until I returned and had a talk with Goerdeler, and I don't think he ever heard of it until the last day of his life," Strölin said in an interview with Brigadier Desmond Young. ${ }^{13}$ The conspirators knew they needed a man with longstanding respect, popularity, and levelheadedness to lead the army; they needed a man like Rommel.

At some point in February 1944, Rommel agreed to join the conspirators and attempt to rescue Germany. ${ }^{2} \mathrm{He}$ was ready to lead a military dictatorship that restored the virtue in the authentic National Socialist program. ${ }^{6}$ Speidel documented Rommel's thoughts about how unmerciful the Allied peace conditions would be in his book Invasion 1994: "[Rommel] hoped for a measure of statesmanlike insight, psychological wisdom, and political planning in the Allied deliberations. He expected no sympathy or any kindred emotion, but he relied on the calculated understanding of the great powers." 10 Rommel's wife verified that he opposed assassinating Hitler because of the possibility of triggering civil war in Germany and Austria. ${ }^{10}$ Instead, he favored an arrest and trial. ${ }^{10}$ However, other events intervened, and, without Rommel's knowledge, on July 20, 1944, the conspirators attempted and failed to assassinate Hitler at his map hut at Rastenburg. ${ }^{2,11}$ Any man suspected of remote involvement was destined for death, including Rommel.

\section{The Accident}

Three days prior to the assassination attempt, Rommel was badly wounded in an air attack. In the early morning of July 17, 1944, a staff car left Rommel's headquarters at La Roche Guyon. ${ }^{2}$ The passengers included Rommel, his aide Captain Helmuth Lang, Major Neuhaus, Sergeant Holke, and their driver, Sergeant Karl Daniel. The journey was one of Rommel's routine inspections of the front line. By January 1944, Hitler had forbidden Rommel from traveling via aircraft, as several high-ranking officers had been killed in air crashes. ${ }^{11}$ Thus, Rommel traveled by automobile to conduct inspection trips of his troops. ${ }^{11}$ On this trip the men visited the command posts of the 277th and 276th Infantry Divisions and continued on to the headquarters of the 1st and 2nd SS Panzer Korps for a meeting with Major General Willi Bittrich and Lieutenant General Josef Dietrich. ${ }^{2}$ At 4 PM, they began the journey back to La Roche Guyon for an 8 PM meeting with Foreign Minister 
Joachim von Ribbentrop. ${ }^{2}$ Rommel sat in the front seat, to the right of Sergeant Daniel. Captain Lang sat behind Rommel with Major Neuhaus behind the driver. Sergeant Holke sat in the middle, looking out for aircraft. ${ }^{2}$

Sergeant Daniel drove through Falaise, St. Pierre-surDives, and toward Livarot. However, 8 Allied dive-bombers stalked the Livarot area, making it impossible to pass. ${ }^{2}$ To avoid that danger, the group headed south on a covered lane that paralleled the road to Vimoutiers. As the car reentered the main road, 2 miles north of Vimoutiers, Sergeant Holke noticed enemy fighter aircraft diving toward the car. ${ }^{2}$ Daniel was instructed to speed up and turn off on a small side road 300 yards ahead, toward a farm near Ste.-Foy-de-Montgommery. ${ }^{2}$ Before the car reached the side road, it was attacked by the first aircraft at a range of about 500 yards. ${ }^{2}$ Sergeant Daniel was hit in the left shoulder and left arm by a canon shell and lost control of the car. ${ }^{2}$ The car swerved into a tree stump on the right side of the road and landed in a ditch on the right side of the road. ${ }^{2}$ Rommel was looking backward holding onto the door, and was thrown from the car as it turned over.,11 Rommel suffered a severe head injury that left him immediately unconscious, and he had deep gashes from the shattered glass. ${ }^{2,11}$ Rommel lay helpless 20 yards behind where the car had finally come to rest (Fig. 2). Captain Lang had jumped out of the rear door as soon as the attack began. Major Neuhaus suffered a pelvis fracture from shell fragments that hit the holster of his revolver, and Sergeant Holke was not injured. ${ }^{2,11}$ After a second strafing pass, Captain Lang and Sergeant Holke ran from shelter to carry Rommel to a small cottage on the side of the road. It was the home of farmer Rémy Miche. ${ }^{2}$
A number of theories have been published about who flew the plane that led to Rommel's injury. Initial reports revealed that an American P-47 flown by Lieutenant Ralph C. Jenkins (US Army Air Corps) was the fighter aircraft. ${ }^{12,13}$ There are also reports of British or Canadian Spitfires piloted by either Canadian Charles Fox of 412 squadron or South African Chris LeRoux of 602 squadron. ${ }^{12}$ There is one report of a British Typhoon piloted by John Robert Baldwin, 193 squadron, as well as a report of Jacques Remlinger of 602 squadron. ${ }^{1}$ Others credit Flight Lieutenant Switzer of 193 squadron. ${ }^{8}$ Captain Lang reported that he saw British fighters, yet the most welldocumented possibility is the aircraft flown by Charles Fox. Fox's flying log for the day describes flying from an Allied air base at Beny-sur-mer in Normandy and strafing an unknown German staff car. ${ }^{13}$

Rommel remained unconscious as he bled from his left eye, mouth, a deep gash in his left temporal region, and several superficial cuts. ${ }^{2,11}$ The obvious disfigurement of his skull in the temporal region led his comrades to believe he was dead..$^{10}$ Captain Lang rode Miche's bicycle to Vimoutiers and returned 45 minutes later with a car. ${ }^{2}$ Lang took Rommel and Daniel to an asylum ("asile" in French) in Livarot called La Providence, a Roman Catholic home for the aged. There, he was examined by the first medical provider that was to examine him, pharmacist Marcel Lescene. Lescene made the following diagnoses: "a fracture of the petrous part of the left temporal bone, a perforation of the left tympanic membrane with blood coming from the external auditory canal." ${ }^{2} \mathrm{He}$ also had sustained a fracture through the left orbital arch, had a weak and thready pulse, and was in a deep coma. ${ }^{2}$ Rom-
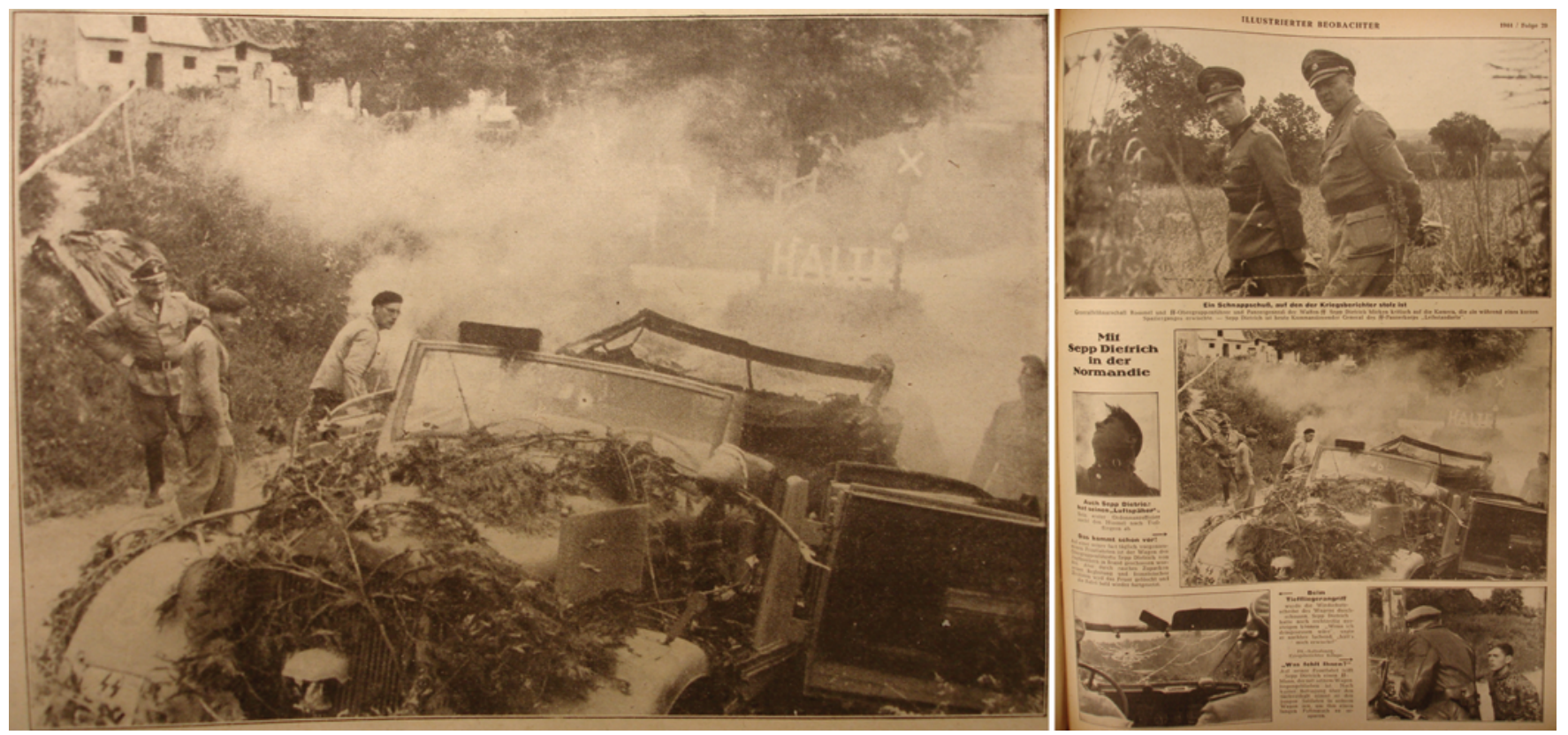

FIG. 2. Photograph (left) reported by several sources to be of the wreckage of Rommel's staff car following the strafing. It was taken by SS Kriegsberichter Kempe and published in the German propaganda paper, Illustrierter Beobachter, on July 20, 1944. The officer at the left of the photograph is SS Obergruppenführer und Panzergeneral Sepp Dietrich. However, when the original paper is examined (right), it is clear from the photo caption and the other text that the wreckage is of Dietrich's car. The confusion may have arisen due to Field Marshal Rommel being pictured in the image at the top of the same page, alongside Dietrich. Public domain. 
mel received 2 ampules of camphorated oil intramuscularly, and Lescene advised that Rommel and Sergeant Daniel be transported to the Luftwaffe Hospital at Bernay, 25 miles away. ${ }^{2}$ At this point, Lescene thought there was little hope of saving Rommel's life. ${ }^{11}$ Sergeant Daniel died at Bernay that night, despite receiving a blood transfusion. ${ }^{2}$

At the Bernay hospital, skull radiographs were obtained, and the staff awaited the arrival of neurosurgical consultant Professor A. Esch. It is debated whether he arrived from Paris the same night or the next morning. ${ }^{2,11}$ Regardless, by the time Professor Esch did arrive, Rommel was restless and given morphine, chloral hydrate, and barbiturates. $^{2}$ Upon initial examination, Professor Esch noted cerebrospinal fluid rhinorrhea and performed a lumbar puncture, which showed clear fluid and no blood. He noted a complete left oculomotor nerve palsy, but described no major motor deficit and no hematoma (neither subdural nor extradural), and concluded that the skull fracture was not depressed. Esch also observed that Rommel responded to strong sensory stimuli and did not recommend any surgical intervention. The anteroposterior and lateral radiographs revealed "severe fracture of the base of the skull running from the right cheek bone through the ethmoid cells and up to the sella turcica."2 As several days passed, it became evident that Rommel was deaf in his left ear, but had no expressive or receptive aphasia. ${ }^{2}$

\section{Recovery}

In the first days of Rommel's recovery, the cerebrospinal fluid leak stopped, and there was no evidence of meningitis or posttraumatic convulsions. ${ }^{2}$ His left eye remained closed (Fig. 3) and his face was still bruised, but over 3-4 days he regained energy. General Hans Speidel and Admiral Friedrich Ruge visited Rommel on July 22, 1944. The following day, Rommel was transferred to L'hôpital du Vésinet in St. Germain, outside of Paris. The car had to drive slowly and deliberately to navigate the bombed roads and bridges, making the 100-mile journey last more than 4 hours. ${ }^{2}$ Professor Esch examined Rommel upon arrival and noticed rapid improvement. Rommel was still not feeling well and in a letter to his wife, written on July 24, 1944, he stated that his "head is still giving [him] a lot of trouble at night."' Although a press conference was held on August 1, it was cut short and there was never a formal announcement in the German press regarding the accident, injury, or hospitalizations. ${ }^{2}$ Three weeks later, an undated announcement was published about the incident, but again silence ensued. ${ }^{10}$ Rommel tried unsuccessfully to broadcast a corrected statement. Rommel believed that Hitler purposefully tried to conceal the facts of the accident so that he could blame Rommel for the failing military circumstances in France. ${ }^{2}$

Rommel feared being captured by the Allies as they advanced through France, so he demanded that he be allowed to return home, against the doctors' objections. ${ }^{11} \mathrm{On}$ August 8, he returned to his home in Herrlingen, accompanied by Professor Esch, Esch's wife, and Doctor Shenning of Army Medical Group B. ${ }^{2}$ Upon his arrival, his 15-year-old son Manfred described the following:

My father, his left eye covered with a black bandage, sat in an

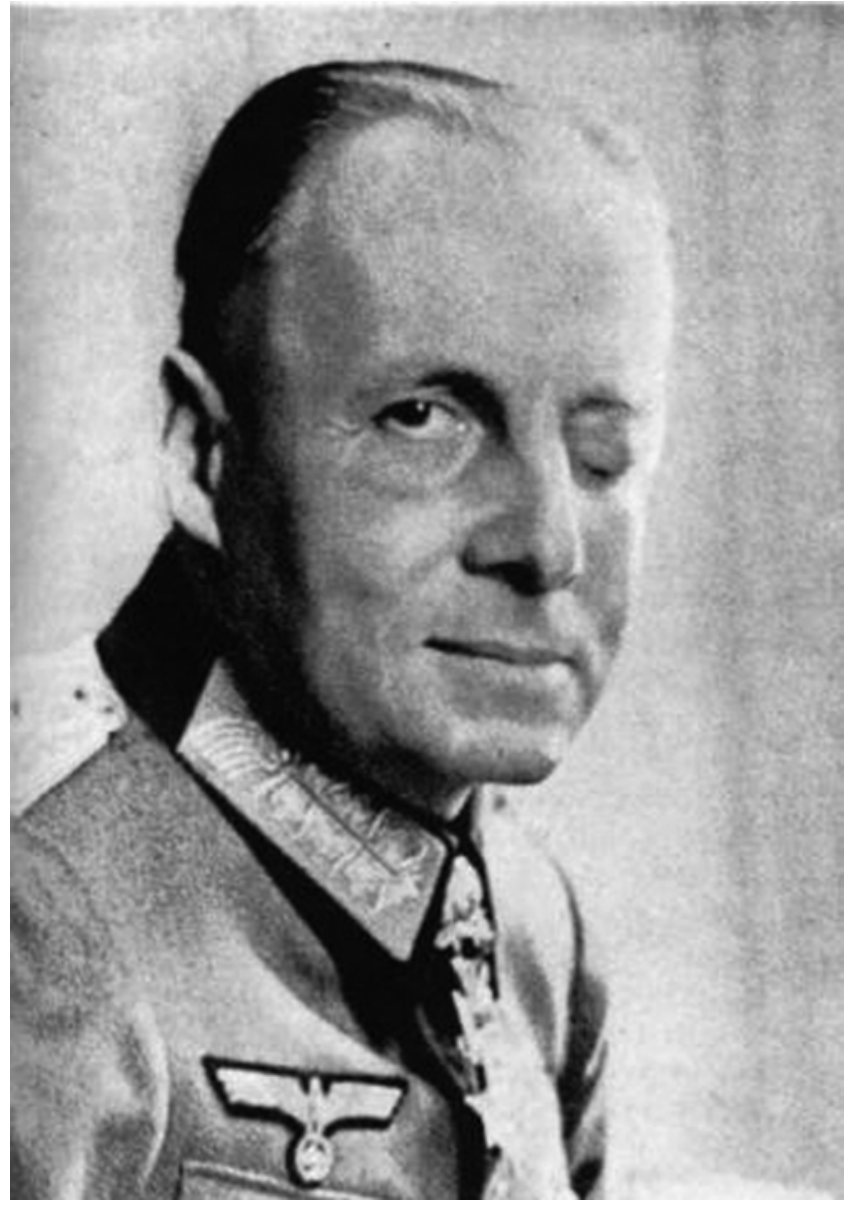

FIG. 3. Photograph of Rommel taken by German war correspondent Baron H. G. von Esebeck at the Luftwaffe hospital in Bernay. Von Esebeck was later the author of a Rommel biography.

arm chair beside a low coffee table. The left half of his face had been crushed by the weight of the blow he had received. He raised himself shakily to his feet and we exchanged greetings. "I still get headaches and my left eye is closed and won't move. But it will all get better."

At home Rommel was attended to by Professors Albrecht of ophthalmology and Stock of neurosurgery, of the University Clinic, Tübingen. ${ }^{1}$ When Professor Albrecht examined Rommel he remarked, "I shall have to revise my lectures to my pupils. No man can be alive with wounds like that."11 Rommel continued to improve, and on September 6, Speidel noticed that his left eye was half open. ${ }^{2}$ During September, the Rommel family discovered that they were being watched by the Geheime Staatspolizei, the official secret police of Nazi Germany and German-occupied Europe. ${ }^{2}$ Rommel's friends warned him that other conspirators had been captured after the July 20 assassination attempt and Rommel was in danger. ${ }^{2}$ On August 17, Field Marshal Günther von Klüge had died by poisoning after being summoned to Berlin. ${ }^{11}$ On September 7, General Hans Speidel was arrested. ${ }^{11}$ Subsequently, Rommel kept his pistol at the ready on his desk, and any time he and Manfred ventured outdoors, they were always armed. Rommel said to his doctor a week before his death: "I am afraid that this madman [Hitler] will sacrifice the 
last German before he meets his own end."10 Rommel wanted the war in the west to be ended under any reasonable conditions whatsoever and quickly before winter, which would vastly favor the Russian armies.

\section{The Final Day}

On October 7 Field Marshal Wilhelm Keitel telephoned Rommel to request his presence at an important conference at the Führer's headquarters in Berlin on October $10 .{ }^{10}$ Rommel was told a special train would collect him from Ulm. ${ }^{7}$ He spoke candidly to Professor Albrecht about the order, immediately after which the doctor said Rommel was not well enough to travel. ${ }^{7}$ Professor Albrecht also tried to convince Rommel to move to his clinic, as it was in a hidden location and Rommel's whereabouts could be more clandestine. ${ }^{7}$ Rommel reluctantly agreed that he and Mrs. Rommel would move on October 20, a date he would never keep. ${ }^{6}$ Because Rommel could not make it to Berlin, he was visited at his home by Generals Ernst Maisel and Wilhelm Burgdorf at noon on October 14. ${ }^{11}$ The men met privately for an hour, allegedly to discuss a new command on the Eastern Front. ${ }^{11}$ However, General Burgdorf informed Rommel that he was suspected of being involved in the July 20 bombing based on the testimony of convicted men. ${ }^{10}$ Burgdorf also told Rommel that the conspirators had established him as Chief of State if a successful uprising had been achieved. Rommel denied both of these accusations. $^{2}$

Following the meeting, Rommel spoke to his wife:

I have come to say goodbye. In a quarter of an hour I shall be dead ... The Führer has given me the choice of taking poison or being dragged before the People's Court. They have the poison. They say it will take only three seconds to act. ${ }^{4}$

If he took the poison, he was promised a state funeral with full honors and was assured that his family would not be harmed. If he opted for trial, conviction and execution would follow, and he expected his family to be persecuted. ${ }^{11}$ Rommel said to Aldinger, "In a quarter of an hour, you, Aldinger, will receive a telephone call from the Wagnerschule reserve hospital in Ulm to say that I've had a brain seizure on the way to a conference." 7 Deeply upset, Aldinger and Manfred proposed that Rommel resist or try to escape. Rommel knew that would be impossible, for the Gestapo men had surrounded the area and were ready to storm the house if any opposition occurred..$^{11}$ Thus, he dressed in his Afrika Korps uniform and cap and bid farewell to his family and Captain Aldinger. ${ }^{11}$

The staff car drove Rommel a few hundred yards away from his house and stopped at an open space. ${ }^{11}$ Rommel and Burgdorf stayed in the car while Maisel and the driver got out. Ten minutes later the driver returned to the car to find Rommel slumped forward with no cap and his field marshal's baton fallen from his hand..$^{11}$ They delivered the body to the Ulm hospital as planned. General Burgdorf gave direct orders to Dr. Meyer, the chief doctor of the hospital, not to perform an autopsy. "Do not touch the corpse," he said. "Everything has already been arranged in Berlin." ${ }^{10}$ Later Dr. Meyer claimed, "One look at the man, and it was obvious he had not died a natural death." ${ }^{6}$ General Burgdorf then traveled to Ulm Wehrmacht Headquarters to telephone Hitler and report Rommel's death. ${ }^{11}$ In The Rommel Papers, Manfred described that 20 minutes later Aldinger answered the telephone and received report of Rommel's death, ${ }^{7}$ after which Aldinger drove to Ulm to identify the body. ${ }^{2}$ Frau Rommel was informed that her husband had suffered a brain hemorrhage and died on his way to Berlin. ${ }^{2}$ Field Marshal Keitel admitted at the Nuremberg trials that Hitler told his closest associates that Rommel had been picking mushrooms while he was recovering at home and the continuous bending down had brought on a stroke, causing his death. ${ }^{6}$

Scholars debate who ordered Rommel's death. A few days after Rommel died, Himmler wrote to Frau Rommel saying that neither he nor Hitler were involved with the poisoning. ${ }^{11}$ This obviously was an admission that it was known at the highest levels to have been a suicide. Some historians believe that Field Marshal Keitel and General Alfred Jodl were the perpetrators. ${ }^{11}$ At the Nüremberg War Crimes Trial, Keitel maintained that the order had come from Hitler. ${ }^{11}$ Keitel and Jodl were later hanged at Nüremberg. Regardless, Hitler ordered national mourning and Rommel was buried with full military honors (Fig. 4) in a small churchyard in Herrlingen. ${ }^{2}$

\section{Discussion}

From Colonel to Field Marshal, Rommel had an impressive rise through the military ranks. ${ }^{5} \mathrm{He}$ could reduce the complexities of war into simple tactical and technical problems.$^{10}$ His sense of opportunism was vital to his success, and he never failed to give the necessary decisive impetus to a crucial action. ${ }^{5}$ Furthermore, his military successes were achieved, in general, with inferior forces and without any air command..$^{5}$ Not only was he a master strategist, he was also an exemplary commander. He accepted large responsibilities and had the mental and emotional capacity to deal with disappointment, setbacks, and "assimilation of defeat when defeat is inevitable." ${ }^{.4}$ His battles at $\mathrm{Al}$ Amein and Tunisia, as well as his attainment of the Panzer division command, attest to his abilities. It is intriguing to speculate what Rommel could have accomplished had he lived, negotiated an armistice with the Allied Powers, ended the war in the West, and assumed German political or military command. The conjectures of how history would have changed, had Rommel had these opportunities and taken them, are endless.

Richard A. Davis, MD, argued that there was little doubt among Rommel's family and military associates that

Had he been able, he would have rallied the German Army to overthrow Hitler and the Third Reich. He most probably would have chosen this course whether or not the explosion had claimed Hitler its victim. When it became known that Hitler had survived on 20 July, 1944, a near panic seized the leaders of the conspiracy, as evidenced by the number of suicides. The need for a calm, resolute leader was essential, and as Rommel lay unconscious at Bernay, none could summon the required courage and boldness. ${ }^{2}$

Rommel proved himself to be an instinctive thinker and problem solver. Charles Douglas-Home, editor of The Times, described the Rommel and Germany that could have been:

If he had ruled Germany, instead of being merely one of her 


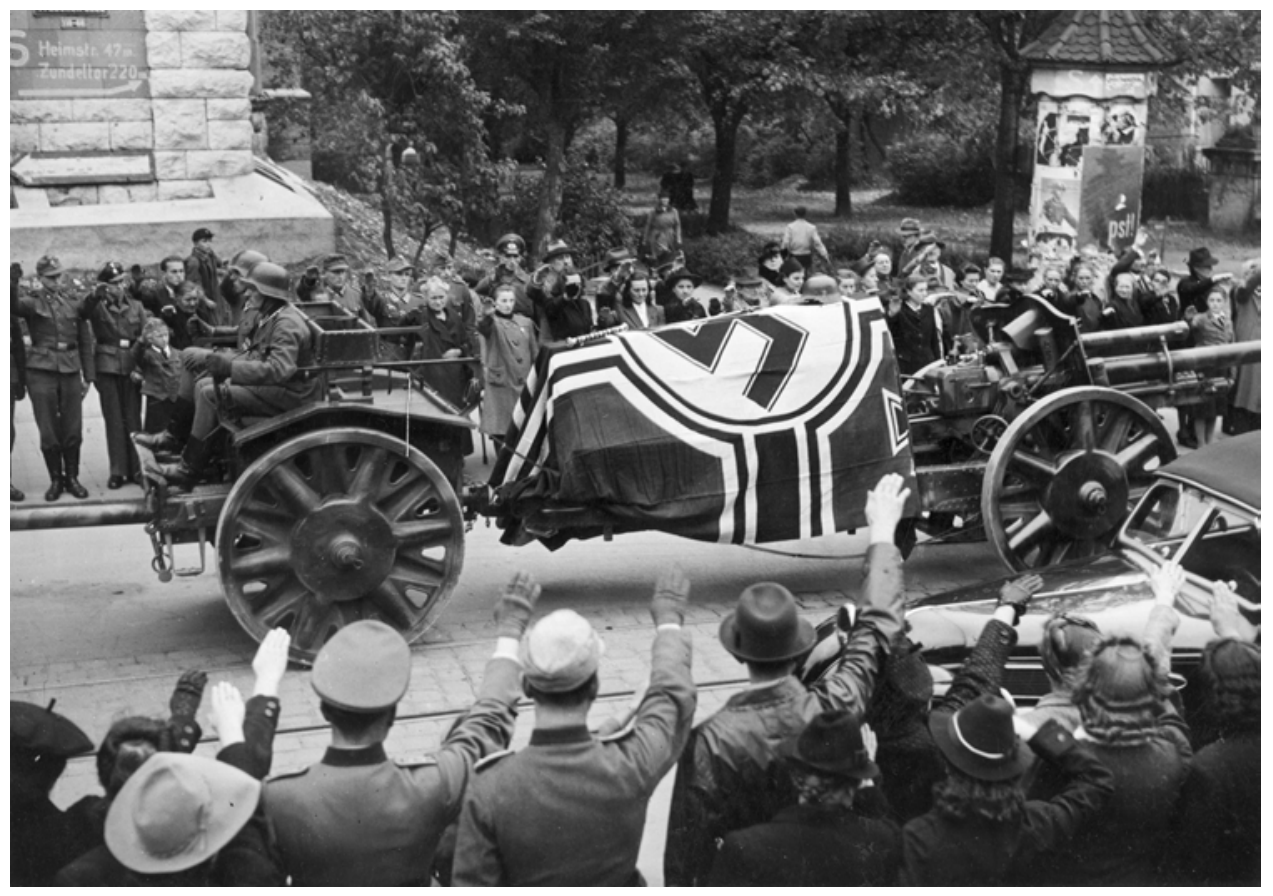

FIG. 4. Photograph of Rommel's military funeral procession. The Reich honored its promise to give him a military funeral and not to persecute his family. Bundesarchiv, Bild 183-J30704, Photographer: Hoffman. CC-BY-SA 3.0; https://creativecommons.org/ licenses/by-sa/3.0/.

generals, he would probably - like Alexander the Great or the Swedish warrior kings - have led German legions into strategies of quite breathtaking extravagance. There would have been many victories; there would have been many defeats; above all there would have been continuous movementcontinuous war-because Rommel's approach to warfare was based on an unbending faith in what the Germans called 'operations', which the British would call maneuvering. ${ }^{3}$

\section{Counterargument}

Despite Rommel's genius, he was criticized for how he executed his ambitions. He often struggled with the administrative details of strategy, planning, and delegation. ${ }^{5}$ His military method was to be everywhere and to do everything. Charles Marshall imagined Rommel's response to a hypothetical problem posed to Marshall at the Officer Candidate School at Fort Knox, Kentucky:

Late one night, read the problem, while on his way to his quarters to catch a little sleep before an important battle, Napoleon came upon a group of unofficered soldiers trying by the light of a lantern to move an artillery piece into position. The hill was steep and the mud deep and they were having trouble. What did Napoleon do? Did he call for the responsible officer and reprimand him? Did he hold the lantern? Did he direct the emplacement? Did he put his shoulder to the wheel? Or did he go to bed so as to be fresh to direct the next morning's battle?

Rommel's solution probably would have read something like this: Napoleon held the lantern, put his shoulder to the wheel, and directed the emplacement; then he called for the battery commander and made certain that the officer's other guns were in position; after that, if he thought the officer at fault, he reprimanded him. If there was any time left, Napoleon went to bed. ${ }^{6}$
The British military historian Ronald Lewin, author of Rommel as Military Commander, also doubts Rommel's long-term leadership abilities and his aptitude to politically run a country.

I have found nothing to disturb my view that his steadily developing antipathy to Hitler was mainly based on a conviction that Germany's military ruin was being caused by Hitler's policies. Those involved in the 20 July plot with which he was to be implicated had many other ideas (social, political or theological) which never entered his head. Rommel had one aim: to win the war for Germany. ${ }^{4}$

Charles Douglas-Home's assessment aligns with Lewin's. Douglas-Home believed that Rommel would shy away from occupying his thoughts with the moral, philosophical, and political workings of the Nazi regime because of his preferred "narrowness of interest and perspective" of war tactics. ${ }^{3}$ Heinz Werner Schmidt, Rommel's Aidede-camp, and author of With Rommel in the Desert, too, had his reservations: "I do not subscribe to the theory that Rommel was a superman. Close to him, I found him much more unimaginative and stolid than the romanticized pictures that have been drawn of him by both friend and foe." ${ }^{9}$

\section{Final Thoughts}

As previously stated, Rommel espoused a code of chivalry. He adamantly opposed Hitler's decree that all enemies should be killed once they crossed the German line. Rommel was not as one-dimensional as Douglas-Home and Lewin declared. Rommel was not only a military commander but a German patriot, a writer, and a leader. Cannot a military genius overtake a dictator? If von Stauffenberg, the chief conspirator involved in the July 
20 bombing, had succeeded, he might have been able to join his "aristocratic fervor" with Rommel's "earthly common sense."4 Lewin admits that this would have been a "formidable combination." With a powerful team leading Germany's revolt against Hitler, it is foreseeable that one man's shortcomings could be made up for by a teammate's strength. In an interview with Desmond Young, Strölin described Rommel as, "not a highly intellectual man; he understood no more of politics than he did of the arts. But he was the soul of honour and would never go back on his word. Moreover, unlike most of the generals, he was a man with the courage to act."13

As evident from his past partnership with Speidel, Rommel could very easily meld with a commanding team. Hans Speidel was an intellect, multilingual, critic of the arts, and meticulous. Kurt Hesse, a friend of both men, told Charles Marshall, "A stronger outer or inner contrast than that presented by these two figures is impossible to imagine, nevertheless, not only did they understand each other, but they complemented one another and worked well together. Each saw the weaknesses and strong points of both and acknowledged them.." ${ }^{\text {A }}$ A pivotal initial move can inspire and ready a force to continue a difficult mission. Rommel most definitely could have been that first move that altered history. He believed that the power of will was more valuable than the power of intellect. ${ }^{6}$ While he was recovering in the hospital from the automobile accident, he said, "Between two courses of action, it is not so important which is chosen as it is that the chosen course be pursued with all possible determination." 6

There is no need to argue that Rommel had all the qualities necessary to be a politician and head of state in order to make the case that he could have changed the course of the war if he had been available when the attempted coup against Hitler occurred. He had the respect of the military, the respect of the German people, and the respect of many of his military opponents. He knew how to build an effective leadership team, and believed in taking action when an opportunity presented itself. He would have agreed with a quote attributed to one of his adversaries in the African Campaign, American General George S. Patton: "In case of doubt, attack." While it may be overreaching to identify the locus of the ultimate outcome and aftermath of World War II for Germany to the single car accident on a road near Ste.-Foy-de-Montgommery, it would be equally remiss to underestimate its impact.

\section{References}

1. Byron R: Who shot Rommel? Tangmere Military Aviation
Museum. (http://www.tangmere-museum.org.uk/articles/ who-shot-rommel) [Accessed May 19, 2016]

2. Davis RA: On a road in Normandy-17 July 1944. [Erwin Rommel]. Surg Gynecol Obstet 113:243-254, 1961

3. Douglas-Home C: Rommel. New York: Saturday Review Press, 1973

4. Lewin R: Rommel as Military Commander. London: Batsford, 1968

5. Liddell-Hart BH: The German Generals Talk. New York: Morrow, 1948

6. Marshall CF: Discovering the Rommel Murder: The Life and Death of the Desert Fox. Mechanicsburg, PA: Stackpole Books, 1994

7. Rommel E: The Rommel Papers. Liddell-Hart BH (ed). New York: Harcourt, Brace, and Company, 1953

8. Rooks D: More than just a mayor-a war hero. Hinton Voice. November 11, 2010. (http://hintonvoice.com/more-than-justa-mayor-a-war-hero-p1046-140.htm) [Accessed May 18, 2016]

9. Schmidt HW: With Rommel in the Desert. London: Harrap, 1951

10. Speidel H: Invasion 1944: Rommel and the Normandy Campaign. Chicago: Regnery, 1950

11. Taylor B: Field Marshal Erwin Rommel: The Desert Fox. Md State Med J 20:35-50, 56-57, 1977

12. Tidy DP: South African air aces of World War II. Military History Journal (South Africa). (http://samilitaryhistory. org/vol014dt.html) [Accessed May 18, 2016]

13. Young D: Rommel: The Desert Fox. New York: Harper \& Brothers, 1950

\section{Disclosures}

The authors report no conflict of interest concerning the materials or methods used in this study or the findings specified in this paper.

\section{Author Contributions}

Conception and design: Sloffer. Acquisition of data: Fuhrman, Mullin. Analysis and interpretation of data: all authors. Drafting the article: all authors. Critically revising the article: all authors. Reviewed submitted version of manuscript: all authors. Approved the final version of the manuscript on behalf of all authors: Sloffer. Administrative/technical/material support: Sloffer.

\section{Supplemental Information}

\section{Previous Presentations}

A portion of this paper was presented as a breakfast seminar oral presentation at the $82 \mathrm{nd}$ meeting of the American Association of Neurological Surgeons, San Francisco, California, April 2014.

\section{Correspondence}

Chris A. Sloffer, Bronson Neuroscience Center, 601 John St., Ste. M-124, Kalamazoo, MI 49007. email: csloffer@yahoo.com. 